\title{
Obliged to calculate: My School, markets, and equipping parents for calculativeness
}

\author{
Brad Gobby \\ School of Education, Curtin University, Perth, Australia \\ GPO Box U1987, Perth, Western Australia, 6845 \\ +61892663795 \\ brad.gobby@curtin.edu.au
}

Biographical note:

Brad Gobby is a lecturer in the School of Education at Curtin University. His areas of research interest include governmentality, the genealogy of the social and the relationship between school reform and governmental rationalities and technologies.

\begin{abstract}
This paper argues neoliberal programs of government in education are equipping parents for calculativeness. Regimes of testing and the publication of these results and other organizational data are contributing to a public economy of numbers that increasingly oblige citizens to calculate. Using the notions of calculative and market devices, this paper examines the Australian Government's My School website, which publishes academic and organizational information about schools, including national test results. While it is often assumed that such performance technologies contribute to neoliberal reform of education through school choice, the paper argues the website is technically limited in its capacity to facilitate the economic calculations and calculated action of parents resulting in school choice. The paper instead opens My School to analysis as a technique of governmental self-formation. Using the theoretical resources of actornetwork theory and Foucauldian scholarship, this paper complicates assumptions in the literature about the extent to which My School actually operates as a 'market mechanism'. It argues My School attempts to cultivate a calculated form of parental educational agency, irreducible to economic market agency.
\end{abstract}

Key words: Calculation, My School, Neoliberalism, Government

\section{Introduction}

Neoliberalism has come to define the 'legitimate' rationalities and means of governing social and economic life in many Western countries, with increasingly marketised, competitive and usercentred institutional environments becoming the norm (Rose 1999; Rose \& Miller 1992). This is the case in the domain of education, where the defining discourses of change are performance, deregulation, enterprise, accountability, and choice (Ball 2005). In Australia, recent neoliberal education policy has viewed education as a sector of the economy "relatively untouched by the big economic reform era of the Hawke and Keating governments" (Gillard 2010b, 5). There has also been an emphasis on autonomy, competition, transparency and responsiveness to users. Performance and benchmarking technologies have been crucial to operationalizing recent reform. In 2008, the Federal Government commenced the National Assessment Program of Literacy and Numeracy (NAPLAN) testing of its school students, and two years later the My School website was launched. The website publishes each school's test results, and other school educational and organizational data. Such reforms reflect the policy as numbers phenomenon, with regimes of testing and benchmarking shaping policies globally, nationally and locally (Gorur 2014; Lingard $\&$ Rawolle 2011). This quantification of education and the 'enumeration' of educational policy and practice depend upon technologies and practices of calculation.

This is an important field of inquiry. Calculation is crucial to regimes of liberal democratic government. In liberal democracies, the exercise of political and governmental power is tied to the 
capacity of formal political authorities and governmental agencies to know and then calculate about domains of existence, including the economy through economic data, and the population through demographic data in censuses (Rose 1991, 1999). Liberal democracies are also committed to a generalization of calculation. Calculative capacity must be dispersed and rendered into a personal activity so that individuals can exercise their autonomy reasonably by calculating about their lives, their commerce, and their work activities. Neoliberalism adds further weight to this necessity. The regulated subjectivities of neoliberalism depend on access to information and data because these enable increasingly 'autonomous' individuals and organizations to calculate about their choices and investments, including in education. While calculation is crucial to politics, government and self-government, the study of calculative devices, calculative practices and their relationship to politics is yet to come under close and sustained inspection (Miller 2008).

The purpose of this paper is to explore the calculative dimension of My School, work already being undertaken by Gorur (2013). Based on the education reform literature, we can confidently begin this examination of $M y$ School from the premise that it incites its users to calculate. $M y$ School is a website established in 2010 by the Australian Curriculum, Assessment and Reporting Authority (ACARA) during the rule of the Australian Labor Party. The party came to power with an education policy calling for an 'education revolution' focused on improving quality and equity. Standardized national testing of students (NAPLAN) commenced in 2008 as a means to provide a clear picture of educational outcomes and to identity those at educational risk across the nation. The My School website collates, organizes and publishes this data, along with other data collected from schools and state education bureaucracies. As a benchmarking technology (Larner \& Le Heron 2004), the website takes account of school performance and indexes it to national standards and the performance of other schools. At the heart of this benchmarking is the idea that quantitative measure of performance can be used to compare spatially and organizationally discrete systems, activities and individuals' (Larner \& Le Heron 2004, 218). This quantification renders calculable the activities and 'performance' of schools by a range of interested groups including parents, principals, teachers and policymakers. The effect of this calculation is 'government by numbers' (Powers 1997; Rose 1999). For example, with 'a new level of sensitivity to the question of 'where are we situated?" (Larner \& Le Heron 2004, 227), performance in measured criteria and the perception of performance become the focus of schools' calculated activities (ALP 2010; Hardy 2014; Lingard \& Sellar 2013; Niesche 2013).

This paper examines the calculative device of My School in relation to parents, an important target user group of the site. My School has been characterized as a political technology for positioning parents more centrally to the provision of education than they are currently by enabling market calculations and school choice. According to Reddon and Low (2012), My School arises 'from a framework of normalized neoliberal assumptions that model public goods on market transactions' (Redden \& Low 2012, 35-36). With the inputs and outputs of schools rendered numerical, each figure putatively 'acts like market data', signaling quality, with the intended effect being that the 'values measured increase' (Redden and Low 2012,36). In this account, My School enables comparisons of quality and in doing so equips parents to 'become competent and capable of exercising choice' (Gorur 2013, 224) in a market of education providers. In the parlance of Callon and Muniesa (2005), My School is a calculative device that contributes to the operation of a market. But, there are questions about how My School operates as a calculative market device. Consider, for example, the ambiguity about how My School is used by parents. The parents in Rowe and Windle's (2012) study 'relegated the 'My School' website to a latter instrument of school choice, with data indicating that whilst most participants viewed data, they have declined to utilize it' $(2012,148)$. This speaks to the complexity of school choice. Choice is shaped by factors like location, government regulation and parental motivation, and parents employ a range of strategies when choosing, including using qualitative information such as school reputation (Ball \& Vincent 1998; Campbell et al. 2009; Francis \& Hutchings 2013). Given these complex influences, My School might not be an effective tool for choice-making. 
The suggestion is not that My School is not a market device animating the market rationalities of neoliberalism. My School is partly forged out of the economic discourses of choice, efficiency and competition. At the time of its development, the discourse of education reform was that reform is to be accomplished through "improved market design - so that we work to create the conditions in which markets serve the public interest through vigorous competition, transparent information, greater choice and becoming more responsive to the needs of service users" (Gillard 2010b, 5). But, My School is irreducible to the status of economic instrument facilitating parent school choice. As the above quote suggests, markets are used to achieve a number of ends, not simply consumer choice, but also transparency and responsiveness. Transparency and responsiveness are related to a powerful and persistent liberal problematisation of state institutions, which concerns the dangers posed by institutions that become closed, ensconced with self-serving interests, and which pose the danger of operating according to principles that undermine the proper conduct of government (Hindess 1998). Therefore, the political objectives of transparency and responsiveness serve to open the institution of schooling to public scrutiny and involvement, with the latter achieved through 'active' citizenship (Dean 1999). Correspondingly, the former Federal Education Minister Julia Gillard argued of My School that 'information is important, it empowers parents' (Gillard 2010a). My School enables parents to avail themselves of data, know their children's school's performance, and then influence the school's service provision (ALP 2010; Gillard 2009; OECD 2012). As well, the former ACARA Chairman Barry McGaw commented 'many parents have no choice' when it comes to choosing a school, and therefore My School 'makes public what was otherwise privately known and produces an obligation to do something if there's a problem' (McGaw cited in Smith 2014, np). We need to be mindful of the different purposes to which My School has potentially been put to use.

This paper employs notions from actor-network theory and Foucauldian scholarship to unsettle commonplace assumptions about the extent My School operates as a market device. These two perspectives inform the paper's notions of calculative device, market device and calculative practice (Callon 1998; Callon \& Muniesa 2005; Miller 2008; Muniesa, Millo, \& Callon 2007), which it uses to explore My School and its relationship to parents and neoliberal government. Following a description of the analytical perspective taken by the paper, I examine the website in light of the notion of calculative market device, with a concern for how its technical assemblage potentially positions parents, and I speculate about whether it facilitates market forms of agency commonly associated with neoliberal political objectives. The examination speculates that $M y$ School's features enable calculations, but the site cannot facilitate a complete choice-making market agency through its use alone. This paper concludes by opening the analysis of My School to its political role as a technology of self-government tied to the abovementioned rationalities of transparency and responsiveness. I contend the site aims to support parents to conduct thems elves as conscientious and informed educational agents by promoting calculativeness and a calculated, but not necessarily choice-making, form of parental agency.

\section{Calculative devices and calculation}

Consonant with the principles of actor-network theory (Latour 2005), Callon (1998) emphasizes the role and associations of non-human material devices, or 'actors', to calculation. Calculative capacities are not purely innate because whether an individual is assessing the value of a school, estimating the cost of a used car, or deciding on a course of action, the individual becomes a 'centre of calculation' (Latour 2005) only by employing devices that enable calculated thought. Callon (1998) writes:

Calculating - we shall limit ourselves here to this point - is a complex collective practice which involves far more than the capacities granted to agents by epistemologists and certain economists. The material reality of calculation, involving figures, writing mediums and inscriptions... are decisive in performing calculations. From the fact that calculations are made in the quasi-laboratories of calculative agencies (the word agent places too much weight on the individual) we should not infer that there are calculative 
beings, no matter how well or poorly informed they may be. From collective performance we cannot induce individual mental competence. (Callon 1998, 4-5)

In short, the 'equipment' of calculation is not entirely situated in the human brain, and instead we must look to social and institutional technologies as the conditions for calculation and calculated action (Callon 1998; Callon \& Muniesa 2005; Fourcade 2007). This speaks to the constitutive nature of calculative devices. Calculative devices render reason and calculation possible. They also render the world intelligible and, under the condition of that intelligibility, make it amenable to certain forms of action, certain kinds of agency (Miller \& Rose 1992).

Pertinently, calculative devices do not enjoin individuals to simply make numerical calculations. The dichotomy between pure rationality and pure judgment creates the spurious belief that calculation is a singular practice of pure numerical operations. But, non-arithmetic qualitative judgment can be calculative too (Lave 1986). Blurring the distinction between calculation and judgment, Callon and Muniesa (2005) posit that calculation 'starts by establishing distinctions between things or states of the world, and by imagining and estimating courses of action associated with things or with those states as well as their consequences' $(2005,1231)$. They outline a three-step process of calculation where calculative devices take a central role in the process:

- First, for calculation to occur, entities must be taken into account by being arranged and organized in a single space: '.. it is the 'account' itself but also, by extension, the surface on which the entities to calculate are moved... then compared and manipulated on the basis of a common operating principle' (Callon \& Muniesa 2005, 1231). These spaces, which may include an invoice, trading screen or a supermarket trolley, constitute different forms of calculation.

- Second, once the entities are sorted, the entities are 'associated with one another and subjected to manipulations and transformations, still in a very material sense' (2005, 1231). Consider, for example, the income and expenditure columns of a spreadsheet, or the comparison of two mobile phones on a webpage.

- The third step is to obtain a result from the previous two steps. 'A new entity must be produced (a sum, an ordered list, an evaluation, a binary choice, etc.), which corresponds precisely to the manipulations effected in the calculative space' $(2005,1231)$. For example, the result of multiplying two figures, or the choice of a mobile phone based on the 'value' of each. The result extracted must 'be able to leave the calculative space and circulate elsewhere in an acceptable way (without taking along all the calculative apparatus)' $(2005,1231)$.

In other words, calculative devices take entities into account, sort and arrange these entities to facilitate comparison and evaluation, and they enable the extraction of a result, or a value of some kind. Accordingly, calculation can 'either meet the requirements of algorithmic formulation or be closer to intuition or judgement' (Callon \& Muniesa 2005, 1232), or 'qualculation' (Cochoy 2008). To what extent does My School resemble a calculative device thus conceived?

\section{My School as a calculative device}

My School can be viewed as a calculative device that seeks to constitute 'school performance' and configure the calculative thought and action of parents. The first step in a calculation is the taking of account, which is a product of 'specific metrological work and heavy investment in measuring equipment' (Callon et al. 2002, 199). My School does this by rendering schools into entities with knowable and calculable qualities. The website is organized around individual schools, rather than indicators, to enable each school's performance to be taken into account. The properties of schools and school performance are contained on the five webpages allocated to profiling each school: (1) 
a school profile page; (2) a school finances page; (3) a NAPLAN results page; (4) statistics on vocational education and training provided; and (5) a local schools page.

The process of taking account requires the construction of what Lingard \& Rawolle $(2011,489)$ refer to as a 'commensurate space of equivalence'. My School constructs this equivalence through the site's standardized organization and the codification of school organization and performance into indicators and categories applied to all schools regardless of context. Depicting all schools according to these standardized attributes means grouping them on a single plane of equivalence, constituting a common 'operating principle' for judgment (Callon \& Muniesa 2005, 1231). Like a balance sheet, a common visibility is accorded to each school for displaying results through the use of standardized charts, grids and graphs. Distinction accompanies this equivalence. Here, through the extraction of 'information' or data collected about each school according to the standardized categories and indicators, each school is carved out as a distinct and knowable entity. In this process of distinction, aided by principal comments, tables, charts and graphs, the qualitative and quantitative differences between schools, their inputs and their outputs are constructed, ordered and made visible and calculable.

This technical construction enables schools to be associated and then evaluated. This is the next step in the process of calculation - associating and comparing the entities taken into account. All calculations require associating entities because comparison and ranking effectively yields the calculating agent a result (Callon 1998). The user is presented with tools that enable comparisons between schools on a range of qualities. Here, the profiling of each school 'consists in establishing a calculative space in which it can be connected and compared to a finite list' (Callon \& Muniesa 2005, 1235). As Gorur's (2013) analysis of My School demonstrates, the numerical depiction of school performance by My School invites certain comparisons and judgments about 'performance'. By enabling comparison (e.g. of staffing, income, expenditure, literacy and numeracy scores, rates of graduation and attendance) and the depiction and detection of variance to a standard, average or ideal, My School incites users to obtain a result, like an estimation of the quality of individual schools, or identifying which local school performs best, identifying which school has the best rate of graduation, or calculating which numeracy or literacy skills require improvement in a particular school. While My School enables calculations, does My School readily enable the making of a judgment of value that produces a course of action?

\section{My School as a market device}

In the analysis of markets, calculative devices and practices are often assumed to play a minimal role in rendering markets knowable and operable (Miller 2008). Many sociological accounts of markets take a sociologically realist and rationalist perspective that assumes the $a$ priori existence of a unified society and market (Fourcade 2007). But, understanding markets means closely studying the technologies and practices that constitute markets in their specificity. The examination of marketisation in education is increasingly attending to the role of technologies, practices, institutions and power dynamics in constituting the relations, spaces and categories through which we think and act society and markets (Gorur 2013). This paper views localized calculative practices and devices as crucial in the contrivance of markets, like education quasimarkets, because individuals must be able to calculate; for example, to 'calculate compromises on the values of goods' (Callon \& Muniesa 2005, 1230). This section offers a close analysis of $M y$ School using Callon and Muniesa's (2005) notion of market device.

So, what constitutes a calculative device as economic? According to Muniesa et al. (2007, 3), 'An economic agencement is, in a broadest sense, one that renders things, behaviours and processes economic'. Here, calculative devices might constitute the goods, agencies and exchanges that compose markets or quasi-markets as calculable goods, calculative agencies and calculated exchanges (Callon \& Muniesa 2005). Calculative market devices are a kind of economic device that emphasizes 'the conception, production and circulation of goods, their valuation, the construction and subsequent transfer of property rights though monetary mediation, exchange 
mechanisms and system of prices' (Muniesa et al. 2007, 4). Market devices render entities knowable as economic goods or as objects of attachment. They may facilitate exchange, such as school prospectuses which attempt to attract enrolments, or circulate economic information, such as benchmarking regimes which feed information into supply chains to improve economic competitiveness (Larner \& Le Heron 2004). Calculative devices are not necessarily economic in nature, but they can be rendered economic through their hybridization with other devices. How, then, does My School compare to such a conceptualization of a market device?

The sociological criticism of My School is that through the practices of comparison the site enables the calculation of school value and the arrival at a choice. My School, it could be said, ascribes to schools a range of qualities, and then positions schools 'in a space of goods, in a system of differences and similarities, of distinct yet connected categories' (Callon, 2002 198). Gorur (2013) describes this as schools being 'systematically tagged, valued, sorted and placed in appropriate aisles and shelves in a kind of virtual supermarket' $(2013,221)$. The value an individual ascribes to a school hinges upon how it compares to other schools, in this case the distinctions that are made between the qualities (e.g. performance data) of each school. In this interpretation, by enabling comparison, the users of My School can estimate, know and rank the value of their options, which then gives the calculating agent their preference (Callon 1998). Accordingly, My School contributes to the political construction of an education quasi-market by facilitating choice and exchange. But, can My School readily produce market agency?

An economic calculation depends on the service of schooling being rendered into a 'calculable good' (of value to the market) that can become the object of an economic transaction. A calculable good is a result of a process of objectification (delimiting a thing), building consumer attachments by giving products qualities, and making goods comparable (Callon \& Muniesa 2005). This process is organized around three key mechanisms: objectification, singularization, and the simultaneous attachment of goods to consumers. If we assume that as a market device My School commoditizes schools, then the 'profiling' of each school represents the process of objectification, or shaping schools into certain kinds of entities; the 'consumer can make choices only if the goods have been endowed with properties that produce distinctions' (Callon \& Muniesa 2005, 1235), and the resulting goods are made comparable to a finite list of other goods. But the formation of calculable goods depends on the process of singularization.

Singularization 'consists in a gradual definition of the properties of the product, shaped in such a way that it can enter the consumer's world and become attached to it' (Callon \& Muniesa 2005, 1233-1234). This is the enactment of an 'economy of qualities' (Callon et al. 2002) where economic actors qualify goods for competitive advantage. With My School, this is largely done through a comment box at the top of each school's profile page. The comment box is an opportunity for each school principal to 'present key aspects of the school, including its mission, values and focus' (ACARA 2013). Through the description, principals invite users to make quality-based rational judgments (Cochoy 2008) as they express the value offered by their school, which cannot be captured by the numbers of test scores alone. These descriptions exemplify 'corporate performance', like that of school prospectuses where schools position themselves favorably in relation to a field of competitors (Meadmore \& Meadmore 2004, 385).

But, My School largely limits the process of singularization to each principal's comments because the qualification of schools, and decisions about how they are presented to the market, occurs with limited market input. In the commercial sphere, economic agents qualify and build consumer interest in a product through a range of mechanisms, including product testing, trialing and consumer feedback. This is how consumers can become attached to goods, or how a 'thing is transformed into a good to which an economic agent assigns a value' (Callon \& Muniesa 2005, 1233). With My School, the qualities of schools are largely pre-determined. The site qualifies schools through political and expert discourses that define the standard criteria for measuring school performance (test results, graduation rates, staff numbers, etc.). Schools and 'the market' exercise little influence over the language, categories or qualities attributed to schools, the 
definition of 'performance', or how schools will be presented on the website. These are stabilized in bureaucratic and ICT networks, and therefore become relatively closed and inflexible.

The problem here is whether parents share the website's normative assumptions about the value of tests, the quality of the measures, and what defines performance. Research suggests many parents might not. Ball and Vincent's $(1998,393)$ study of the use of "grapevine knowledge" in the selection of schools found "the social contexts of choice are as or more important than the abstract/objective qualities of goods." School reputation, proximity to home, and the use of traditional forms of discipline, curriculum and pedagogy are identified as more important factors in choice making than academic quality (Campbell et al. 2009; Whitty et al. 1998). Despite this, the standard formatting of My School dictates to My School users that schools and their activities, outcomes and value are to be known and judged according to 'objective' measures. The lack of parental input into this process of qualification potentially leads to a weak attachment to schools and the qualities, classifications and evaluative principles underpinning the site. Moreover, the standardized format, while facilitating comparison, results in limited singularization and this produces weak attachment and strong substitutability when it comes to arriving at a judgment or obtaining a result (Callon \& Muniesa 2005). Relatedly, My School is not equipped to build these attachments because it restricts the processes of requalification, which is 'at the heart of the dynamics of economic markets' (Callon et al. 2002, 200). For Callon et al., requalification is 'the ability to modify the list of qualities' and 'is a strategic resource since it is a matter of positioning the good in a space of goods' (Callon et al. 2002, 200). My School does not facilitate this process as schools are constrained in adjusting and responding to potential 'purchasers' or competitors. This disables them from giving their schools value as a calculable good that parents can readily become attached. Consequently, in order to form an attachment and accomplish a choice, users might need to utilize other calculative devices and practices that give schools value.

The final step in an economic calculation is for a consumer to obtain a result in terms of choice, where we could expect the resulting entity 'to be able to leave the calculative space and circulate elsewhere in an acceptable way' (Callon \& Muniesa 2005, 1231). My School does not readily enable this. While the data on the site indicates quantifiable reference points that parents can calculate, these do not indicate the overall value proposition of a school. My School does not directly inform parents which schools are superior - there is, for instance, no ranked list. The website has avoided this, and it stops third parties from doing so through a Terms of Use agreement. My School instead expects users, who have varying levels of literacy, to interpret the voluminous data provided to them. While a market requires access to information about a good or product for informed calculated decision-making (Callon \& Muniesa 2005), too much information inhibits the practice of estimating value and ranking through comparison, producing a situation of 'non-calculation' (Callon \& Muniesa 2005, 1232). Even if a user does arrive at a choice, My School limits the capacity for exchange. Compare, for instance, My School to the techniques of retail websites whose goal is to unashamedly obtain from its user a choice and an exchange. Retail, comparison and aggregate websites facilitate choice making through simple graphic indicators of overall quality or value, and customer reviews. These techniques enable the user to conduct himself or herself as a purchaser capable of arriving at a calculated judgment of value, and to act on this judgment by executing a choice. My School, however, does not effectively embed school data into such economic agencements that could facilitate direct economic choice making and exchange.

Summarily, then, as a calculative device, My School renders schools into calculable and comparable entities and its users into calculating agents comparing and judging aspects of schools and school performance. However, overall My School's features do not effectively render schools into calculable economic goods that appeal to most consumers, nor many parents into calculating consumers. The claim I make here is speculative because no empirical research was conducted into parents' actual choice-making behavior, and little research exists of parents' use of the site. Nevertheless, analyzing the website using the notion of market device allows us to speculate that choice-making agencies are not readily producible by the website. This may in fact reflect the 
quasi-market nature of the education market - the site creates and responds to a market heavily shaped by political and bureaucratic objectives, rationalities, and regulations, rather than consumer desires and values. This is not to claim the website is a failure, or that people cannot use it to make economic or school choices. If we shift the focus to principals' use of My School, the site can be deployed in economistic regimes of competition (Niesche 2013). That said, the above analysis cautions against essentialising the website as an 'instrument of economic rationality, which simply by being used, imposes on the agents a coherence and calculating logic that is beyond their reach' (Callon \& Muniesa 2005, 1237).

\section{Concluding remarks}

I conclude this paper by turning to Foucauldian scholarship to offer a perspective on the calculative agency of parents' use of My School. In particular, I am interested in how political and governmental authorities deploy a 'whole range of practices that constitute, define, organize, and instrumentalize the strategies that individuals in their freedom can use in dealing with each other' (Foucault 1997, p. 300; Foucault 2008), or indeed to use in relation to him/herself in their practice of self-government. The concern here is with how technologies like My School are potentially used as technologies of government and self-formation. In education, managerial technologies within organizations have driven calculative practices through which workers (professionals, managers, etc.) construe and conduct themselves as entrepreneurial, economic, self-responsible, prudent and moral subjects of government (Gobby 2013; Peters 1996). In concerning myself with the subjective-ethical formation of parents through My School, I am mindful of Miller's (2008) analytical attention to the political and governmental ideals attached to certain calculative technologies, and how these shape the conditions of individual and collective conduct to specified ends (Miller \& Napier 1993; Rose, 1991; Rose \& Miller 1992). He argues that the "technological turn' to the analysis of the economy and markets has yet to be matched by a 'similar concern with the programs or 'ideas' that articulate, animate and give significance to particular ways of calculating' (Miller 2008, 53). Unlike the current literature on My School, this final section explores the website in relation to the powerful political discourses of transparency, responsiveness and 'active citizenship' mentioned in the introduction.

While the data generated within organizations, like education systems, were once kept within those confines, neoliberalism has transformed the access to and use of data. Data is now moving beyond professional, bureaucratic and governmental enclosures. Today, data related to government services is reaching into the family home, with websites like MyUniversity, MyHealth, MyAgedCare and My School exemplifying this incursion. The creation of these 'my tools' of agency represents a neoliberal transformation of social and economic government. Here, public service providers are opened to greater public scrutiny and influence, and citizens are expected as a matter of social, economic and moral obligation to be active in their self-government (Rose 1999). As active agents, citizens must involve themselves in the institutions of government that attempt to govern them, or exercise choice in their use of services. In education, deregulation, privatization and school choice policies discursively mobilise the figure of the active parent. Although activating parental educational agency and decision-making is an historical phenomenon (Hunter 1993; Smith 1993), governments over the last couple of decades have intensified their attempts to transfer to parents many responsibilities (such as for school enrolments) that were previously those of education bureaucracies. Leaving decision-making to the state is increasingly construed as risky, even irresponsible. In effect, parents must calculate their interest as prudent and informed subjects of risk (O'Malley 1996), and this requires access to 'information', to data. Governments are therefore committed to distributing calculability and calculativeness. My School enacts this transformation to parental agency.

My School emerged in an ensemble of educational reforms associated with the political goals of increasing parents' educational agency, and 'improving market design - so that we work to create the conditions in which markets serve the public interest...' (ALP 2010, 5). As a calculative tool, My School is a technique of power that proposes new calculative practices linked to the objective 
of 'changing the way Australian parents think and talk about our schools' (ALP 2010, 7).

Providing the tools to compare and assess schools according to mainly quantitative organizational and performance criteria, My School positions parents as active calculators of school performance. It is a matter of individual, economic and social responsibility that parents calculate to 'know the facts', and to accomplish responsible and informed decisions. My School should be regarded as a pedagogical techne that fashions the self as it shapes the forms of calculation of its users. It is one means to "establish and promote particular human capacities - including those we might wish to regard as 'reasoning' - within bodies of knowledge and types of rationality, forms of power and government, and ethical practices' (Dean 1994, 63). The ethical ideal established for parents is an arguably calculative parental agency. My School equips parents with calculativeness, and the obligation to engage in a form of calculation or forethought about their child's education, and about the provision of governmental services and their use of them, as one might in other arenas of life. Through technologies of My School, parents are 'schooled' into calculating using politically-valued forms of calculation and reasoning (e.g. test data). Given the broader neoliberal reforms to schooling, it is becoming an inescapable responsibility for parents to actively negotiate the risky educational space..

This parental activation must not be narrowly conceived as the sovereign consumer seeking maximum utility and advantage through market exchange (Wilkins 2010). While My School is a calculative device that can inform judgments about schools, when it comes to parents, its design limits economic calculability, including the extraction of an economic result. I contend the site does not effectively orchestrate attachment and the deployment of choice, and the site might struggle to effectively enroll parents into its use as a decision tool (see Rowe \& Windle 2012). While some people may use My School as a tool for choice-making, given the limitations identified in this paper and the qualitative nature of the calculations parents are known to make about schools, the website might prove to be marginal to this process. But, even if My School is a potentially ineffective market device for the purpose of securing choice-making conduct broadly as I have speculated, it nevertheless reflects an increasing obligation of citizens to participate in their own self-government. The enrolling of parents into its use is tied to the cultivation of the modern parent whose thoughts and behaviours must subscribe to what Callon and Muniesa (2005) observe as an emerging single implacable logic that is becoming hegemonic: that of calculation as the only possibility for action. I contend that My School reflects an emerging obligation in the education domain that parents should be active educational agents, and a condition of their activity should be calculation, and specifically the forms of calculation enjoined by My School.

\section{References}

Australian Curriculum, Assessment \& Reporting Authority [ACARA]. 2013. School Comments Writing Guidelines. http://www.schools.My School.edu.au/ContactUs/Usingtheportal

Australian Labor Party [ALP]. 2010. School Reform: Making Every School a Great School. http://parlinfo.aph.gov.au/parlInfo/search/display/display.w3p;query=Id\%3A\%22library\%2Fparty pol\%2FKGOX6\%22

Ball, S. 2005. Education Policy and Social Class: The Selected Works of Stephen J. Ball. Oxon: Routledge.

Ball, S. \& Vincent, C. 1998. “'I Heard it on the Grapevine': 'Hot' Knowledge and School Choice.” British Journal of Sociology of Education 19 (3): 377-400. doi: 10.1080/0142569980190307

Callon, M. (1998). "Introduction: The Embeddedness of Economic Markets in Economics." The Sociological Review 46 (1): 1-57. doi: 10.1111/j.1467-954X.1998.tb03468.x

Callon, M., Meadel, C. \& Rebeharisoa, V. 2002. "The Economy of Qualities." Economy and Society 31 (2): 194-217. doi: 10.1080/03085140220123126 
Callon, M. \& Muniesa, F. 2005. "Peripheral Vision: Economic Markets as Calculative Collective Devices.” Organization Studies 26 (8): 1229-1250. doi: 10.1177/0170840605056393

Campbell, C., Proctor, H. \& Sherrington, G. 2009. School Choice: How Parents Negotiate the New School Market in Australia. Crows Nest: Allen \& Unwin.

Cochoy, F. 2008. "Calculation, Qualculation, Calqulation: Shopping Cart Arithmetic, Equipped Cognition and the Clustered Consumer." Marketing Theory 8: 15-44. doi:

$10.1177 / 1470593107086483$

Dean, M. 1994. Critical and Effective Histories: Foucault's Methods and Historical Sociology. London: Routledge.

Dean, M. 1999. Governmentality: Power and Rule in Modern Society. London: Sage Publications.

Foucault, M. 1997. Ethics, Subjectivity and Truth. The Essential Works of Michel Foucault, 19541984 (Vol. 1). New York, NY: The New Press.

Foucault, M. 2008. The Birth of Biopolitics: Lectures at the College de France 1978-1979. Hampshire: Palgrave Macmillan.

Fourcade, M. 2007. "Theories of Markets and Theories of Society." American Behavioral Scientist 50 (8): 1015-1034. doi: 10.1177/0002764207299351

Francis, B. \& Hutchings, M. 2013. Parent Power? Using Money and Information to Boost Children's Chances of Educational Success. The Sutton Trust. UK.

Gillard, J. 2009. A New Progressive Consensus for Australian Schools. Presentation to the Brookings Institution. June 2009.

Gillard, J. 2010a. Gillard Urges Parents to Use Website to Improve Schools. January 28. http://www.abc.net.au/am/content/2010/s2803248.htm

Gobby, B. 2013. "Principal Self-government and Subjectification: The Exercise of Principal Autonomy in the Western Australian Independent Public Schools Programme." Critical Studies in Education 55 (3): 387-397. doi: 10.1080/17508487.2013.832338

Gorur, R. 2013. “My School, My Market." Discourse: Studies in the Cultural Politics of Education, 34 (2): 214-230. doi: 10.1080/01596306.2013.770248

Gorur, R. 2014. "Towards a Sociology of Measurement in Education Policy." European Educational Research Journal 13 (1): 58-72. doi: 10.2304/eerj.2014.13.1.58

Hardy, I. 2014. "A Logic of Enumeration: The Nature and Effects of National Literacy and Numeracy Testing in Australia." Journal of Education Policy. doi:

10.1080/02680939.2014.945964

Hindess, B. (1997). A Society Governed by Contract? In G. Davis, B. Sullivan, and A. Yeatman (Eds.), The new contractualism? (pp. 14-26). South Melbourne: Macmillan Education Australia.

Hunter, I. 1993. "The Pastoral Bureaucracy: Towards a Less Principled Understanding of State Schooling." In Child and Citizen: Genealogies of Schooling and Subjectivity edited by D. Meredyth, \& D. Tyler, 238-286. Brisbane: Griffith University. 
Larner, W. \& Le Heron, R. 2004. "Global Benchmarking: Participating 'At a Distance' in the Globalizing Economy." In Global Governmentality: Governing International Spaces edited by W. Larner \& W. Walters, 213-232. Oxon: Routledge.

Latour, B. 2005. Reassembling the Social: An Introduction to Actor-Network-Theory. Oxford University Press: New York.

Lave, J. 1986. "The Values of Quantification.” In Power, Action and Belief: A New Sociology of Knowledge? edited by J. Law, 88-111. London: Routledge \& Kegan Paul.

Lingard, B. \& Rawolle, S. 2011. "New Scalar Politics: Implications for Education Policy." Comparative Education 47 (4): 489-502. doi: 10.1080/03050068.2011.555941

Lingard, B. \& Sellar, S. 2013. “'Catalyst Data': Perverse Systemic Effects of Audit and Accountability in Australian Schools." Journal of Education Policy 28 (5): 634-656. doi: 10.1080/02680939.2012.758815

Meadmore, D. \& Meadmore, P. 2004. "The Boundlessness of Performativity in Elite Australian Schools." Discourse: Studies in the Cultural Politics of Education 25 (3): 275-287. doi: 10.1080/0159630042000247944

Miller, P. 2008. “Calculating Economic Life.” Journal of Cultural Economy 1 (1): 51-64. doi: $10.1080 / 17530350801913643$

Miller, P. \& Napier, C. 1993. "Genealogies of Calculation.” Accounting, Organizations and Society 18 (7/8): 631-647. doi: 10.1016/0361-3682(93)90047-A

Muniesa, F., Millo, Y, \& Callon, M. 2007. “An Introduction to Market Devices.” In Market Devices edited by M. Callon, Y. Millo, \& F. Muniesa, 1-57. Maiden, MA, USA: Blackwell Publishing.

Niesche, R. 2015. "Governmentality and My School: School Principals in Societies of Control." Educational Philosophy and Theory 47 (2): 133-145 doi: 10.1080/00131857.2013.793925

OECD. 2012. Delivering School Transparency in Australia: National Reporting Through My School. Paris: OECD Publishing. doi: 10.1787/9789264096660-en

O'Malley, P. 1996. "Risk and Responsibility." In Foucault and Political Reason: Liberalism, Neo-liberalism and Rationalities of Government edited by A. Barry, T. Osborne \& N. Rose, 189207. London: UCL Press.

Peters, M. 1996. Poststructuralism, Politics and Education. Westport, CT: Bergin \& Garvey.

Powers, M. 1997. The Audit Society: Rituals of Verification. Oxford: Oxford University Press.

Redden, G. \& Low, R. 2012. "My School, Education, and Cultures of Rating and Ranking." Review of Education, Pedagogy, and Cultural Studies 34 (1-2): 34-48. DOI:

10.1080/10714413.2012.643737

Rose, N. 1991. "Governing By Numbers: Figuring Out Democracy.” Accounting, Organizations and Society 16 (7): 673-692. doi: 10.1016/0361-3682(91)90019-B

Rose, N. 1999. Powers of Freedom: Reframing Political Thought. Cambridge: Cambridge University Press. 
Rose, N. \& Miller, P. 1992. "Political Power Beyond the State: Problematic of Government." British Journal of Sociology 43 (2): 173-205.

Rowe, E. \& Windle, J. 2012. "The Australian Middle Class and Education: A Small-scale Study of the School Choice Experience as Framed by 'My School' Within Inner City Families." Critical Studies in Education 53 (2): 137-151. doi: 10.1080/17508487.2012.672327

Smith, B. 1993. "Educational Consumerism: Family Values or the Meanest of Motives?" In Child and Citizen: Genealogies of Schooling and Subjectivity edited by D. Meredyth \& D. Tyler, 181205. Brisbane: Griffith University, Institute for Cultural Policy Studies.

Smith, A. March 8, 2014. "Schools Site Receives More Crosses Than Ticks." Sydney Morning Herald. http://www.smh.com.au/national/education/schools-site-receives-more-crosses-than-ticks20140307-34chq.html

Whitty, G., Power, S. \& Halpin, D. 1998. "Devolution and Choice in Education: The School, the State and the Market". Buckingham: Open University Press.

Wilkins, A. 2010. "Citizens and/or Consumers: Mutations in the Construction of Concepts and Practices of School Choice.” Journal of Education Policy 25 (2): 171-189. doi:

$10.1080 / 02680930903447671$ 